\title{
THE POLITICAL ECONOMY OF POLICY CREDIBILITY: THE NEW-CLASSICAL MACROECONOMICS AND THE REMAKING OF EMERGING ECONOMIES
}

\author{
llene Grabel \\ Working Paper \#269 - June, 1999
}

Ilene Grabel, former Kellogg Institute Visiting Fellow (fall 1998), is Associate Professor of International Finance of the Graduate School of International Studies and Codirector of the Global Finance, Trade and Economic Integration graduate program at the University of Denver. Professor Grabel has also served in the UN Expert Group on Financial Crises in Emerging Democracies and the US Information Service Economic Speakers' Program at the Universidad Nacional Autónoma de México (UNAM), as a Postdoctoral Fellow at the Center for Advanced Study in the Behavioral Sciences at Stanford University, and as a policy research and design consultant for the Financial Democracy Campaign. Among her most recent publications are "Coercing Credibility: Neoliberal Policies and Monetary Institutions in Developing and Transitional Economies" in Political Economy of Central Banking (P. Arestis and M. Sawyer, eds., 1998); "Speculation" in the Encyclopedia of Political Economy (P. O'Hara, ed., 1998); and "Savings, Investment and Functional Efficiency: A Comparative Examination of National Financial Complexes" in The Macrocosms of Finance, Saving, and Investment (R. Polin, ed., 1997).

The Kellogg Institute provided invaluable support for undertaking revisions on this paper. An earlier version was presented at the Faculty of Economics and Politics, Cambridge University, Cambridge, England, 19 May 1997. Philip Arestis, Paul Burkett, Ha-Joon Chang, George DeMartino, Gary Dymski, John Henry, Julio Lopez, Jaime Ros, David Ruccio, Malcolm Sawyer, and Jan Toporofsky provided useful comments on this paper. 


\section{Introduction}

The last quarter of the twentieth century will undoubtedly be regarded as an era of fundamental economic revolution-a revolution in which diverse economies in the North, South, and East underwent a radical transformation toward a neoliberal form of capitalism. As Polanyi (1944) rightly argued in the context of earlier revolutions, this 'great transformation' is the product of political contest and ideological struggle rather than the unfolding of some natural historical process. Providing theoretical justification for this transformation stands new-classical macroeconomic theory. ${ }^{1}$ In particular, the new-classical notion of 'policy credibility' has come to cement the case for the desirability and indeed inevitability of economic reconstruction along neoliberal lines.

This paper focuses attention on the role of the concept of policy credibility in the broader neoliberal project to elevate 'the market' as the principal means for directing economic affairs. The neoliberal agenda therefore comprises privatization of state-owned enterprises, reductions in the state provision of services, elimination of state involvement in price setting, and severe restrictions on state manipulation of fiscal and especially monetary policy in pursuit of good economic outcomes. The institutional concomitants of this effort to insulate the market from political interference therefore include the creation of central banks and currency boards that are independent of direction by state representatives. The paper will focus initially on the credibility criterion in the abstract but will then show how the credibility thesis applies to each of these specific policy and institutional reforms as part of the larger project of neoliberal reconstruction of developing and former communist countries (hereafter referred to as 'emerging economies').

The paper interrogates the theoretical adequacy and political legitimacy of the contemporary use of the credibility criterion in debates over economic policy and institutional reform in emerging economies. I argue that the purchase of the concept of credibility requires the truthfulness of assumptions about the epistemic condition in which economic actors live and the economic models that these actors use to interpret economic events. I contend that these assumptions are both implausible and self-serving insofar as they are tailored to justify the kinds

1 The term 'neoliberal' will be used throughout to refer to the free-market economic policies that derive from new-classical macroeconomic theory. New-classical macroeconomic theory emerged in the 1970s and 1980s as an extension of neoclassical economic theory. It combines the 'rational expectations' hypothesis with a presumption of instantaneous market adjustment. Seminal works in the new-classical tradition include Frydman and Phelps (1983), Kydland and Prescott (1977), and Lucas (1973). 
of policies and institutions that new-classical theory embraces. I will also argue that proponents

of the credibility criterion are misguided in assuming that policy credibility is exogenously determined. Rather, I argue that the credibility of any economic policy is endogenous and founded on political power rather than on epistemological adequacy. As a consequence, I will demonstrate that the new-classical notion of credibility invalidates intellectual and political dissent over the range of policies and institutional structures that are worthy of consideration by reformers. The paper concludes by outlining alternative criteria for assessing policy adequacy.

\section{Credibility in Theory and Policy ${ }^{2}$}

\subsection{Credibility Theory}

The preoccupation of development economists with policy credibility emerged on the heels of two developments-one empirical and one theoretical. On the empirical level, the failure of the ambitious efforts at neoliberal economic reconstruction in South America in the late 1970s and early 1980s promoted a search for new strategies among advocates of these reforms. By the mid-1980s a consensus had emerged among new-classical development economists that despite the appropriateness of the neoliberal prescription for South America, the reform agenda nevertheless failed to achieve its intended results because its architects had not taken into account the overall 'policy environment' in which these programs were implemented (Grabel 1996a).

On the theoretical level, the current preoccupation with policy credibility stems directly from the precepts of new-classical macroeconomic theory. The seminal work of Kydland and Prescott (1977) was particularly important to the development of the theory of policy credibility. ${ }^{3}$ In this approach, rational agents use the singular correct economic model and take into account all available information when forming expectations about the future. Among other things, agents must assess the credibility of an announced policy when forming expectations and making judgements about what actions to take. Unfortunately, assessing policy credibility is no simple

2 Note that institutions and policy are treated herein as analytically distinct, but in practice they are thoroughly interdependent. For example, neoliberal support for an independent central bank is tied to the view that such an institution is uniquely qualified to pursue neoliberal monetary policy. Moreover, the policy of privatization seeks to create a particular kind of institution, namely, privatized firms that are driven strictly by market criteria.

${ }_{3}$ There are numerous surveys of the policy credibility literature, e.g., Alesina and Tabellini (1988), Blackburn and Christensen (1989), Cottarelli and Giannini (1997), and Persson (1988). 
matter. At issue are the perceptions of economic actors concerning the viability and effectiveness of announced policies, policymakers' commitment to sustain them, and hence, the likelihood of policy reversal or collapse. The credibility argument, then, depends on a kind of circular logic:

economic policies are deemed effective only if they are credible to private agents; but policies are deemed credible only if they are seen to be effective (Blackburn and Christensen 1989, 1).

How could economic policy be developed in this complex environment, in which the success of policy depends critically on agents' perceptions of its viability? There are essentially two choices: one could shade policy toward existing popular sentiments; or one could implement 'correct' policy, policy that respects the economic fundamentals of new-classical theory. The former option is ruled out of court on the simple grounds that 'incorrect' policy could not possibly retain credibility in the wake of the disruptions that would inevitably attend it. The latter, on the other hand, would induce credibility as it proved itself uniquely capable of promoting development and economic growth, even if it were to be unpopular in the short run. A correctly specified policy would therefore impel rational agents to act 'properly,' at once achieving growth and stability and the credibility necessary to sustain itself.

\subsection{Credibility Theory and Neoliberal Policy}

These theoretical insights have directly informed the character and speed of neoliberal reform programs in emerging economies. In the former communist countries the credibility criterion is at the heart of debates over the timing of economic reform. In countries embarking on a transition to capitalism, policy credibility is taken to be an especially important issue because of the revolutionary nature of the societal transformation (Schmieding 1992). In this connection, 'shock therapy' reform rather than 'gradualism' is deemed by most economists today to be the more credible reform path (Bhattacharya 1997; Murphy et al. 1992; Sachs 1993). ${ }^{4}$ Shock therapy is thought to be more credible than gradualism because rapid reform programs send agents uniform, consistent information about the direction of the economy. Shock therapy is also seen to be more efficient-and hence credible-because reformers have an opportunity to implement radical change only in the early moments of a new regime (this is termed the 'honeymoon

4 By contrast, Dewatripont and Roland (1995) argue for gradualism because it introduces far less political opposition than does shock therapy. Accordingly, they argue that gradualist reforms are more credible because they are less likely to inspire a backlash among dislocated groups (and hence, these reforms are more likely to be sustained). 
hypothesis') before the opposition is able to disrupt the reform agenda (when what's termed 'reform fatigue' sets in).

In this connection, an important component of neoliberal reform involves dismantling nonmarket mechanisms that allocate resources, set prices, and direct other economic outcomes. Neoliberal reform programs throughout emerging economies have therefore included the privatization of state-owned or state-controlled industries (see survey in Anderson and Hill 1996). The sale of bloated and/or ailing firms to private investors signals the government's commitment to abide by market outcomes. Economic actors' energies are therefore redirected away from rent seeking toward productive activity that enhances social welfare.

In emerging economies investor response is taken to reveal or demonstrate the credibility of these reform efforts. The infusions of domestic and foreign capital (or the reversal of capital outflows) that often follow the adoption of neoliberal economic reforms are taken as independent evidence of the credibility of these efforts. For example, Chile's move to neoliberalism in the late 1970 s and early 1980s was seen to be validated by foreign investors. By 1981 vast inflows of foreign capital (equal to $25 \%$ of GDP), coupled with the celebration by the international business press of the Chilean 'miracle,' conveyed credibility to the government's reforms (Conley and Maloney 1995). The same dynamic played out after the initial embrace of shock therapy in Poland and Russia (Gowan 1996) and in the aftermath of Mexico's 'rehabilitation' in the late 1980s and again following the resolution of the financial crisis in 1996 (Grabel 1996b).

During the Asian financial crisis of 1997-8 the leaders of Brazil, Argentina, Hong Kong, and Singapore attempted (successfully) to signal nervous investors that their own commitment to neoliberal policy was highly credible. In the Brazilian case President Cardoso embarked on what was widely regarded to be a highly credible effort to intensify his already stringent program of neoliberal reform. In the context of the crisis President Cardoso was able to convince the lower chamber of Brazil's Congress to approve 51 new pieces of individual legislation that drastically reduced government spending, raised taxes and interest rates, ended job protections for civil service workers, and increased the pace of the government's three-year privatization program (New York Times 1997). Despite the severe recession that resulted from these measures, President Cardoso's efforts were taken to be so credible that the initial investor exit from Brazil in the fall of 1997 was quickly stemmed, and the country weathered the Asian crisis that spread to 
other emerging economies. Argentina's President Carlos Menem embarked on a similar program to speed the pace of neoliberal reform in efforts to signal investors that his country was not going the route of Asia. In efforts to make credible their commitment to prevent the spread of the Asian crisis to their economies, the monetary authorities of Hong Kong and Singapore announced that they would be prepared to let interest rates rise to any level necessary to reverse flight from their countries. ${ }^{5}$

Governments cannot successfully calm investors (and retain access to private capital inflows) by merely announcing neoliberal reforms, of course. A neoliberal reform program that is not credible-either because it is not economically or politically sustainable or because the government's commitment to it is questionable-will do nothing to induce private investment to return to the country (or terminate its exit). Hence, neoliberal reform programs themselves are not intrinsically credible. For example, private investors (rightly) refused to validate former Indonesian President Suharto's frequent announcements of his commitment to neoliberalism during the winter of 1997 and the spring of 1998. The same was true in Russia during the fall of 1998: by that time, investors and the International Money Fund (IMF) had grown (understandably) wary of the government's empty promises to recommit to neoliberal reform.

External validation of the credibility of neoliberal reforms is provided not only by private foreign investors but also by powerful multilateral institutions like the International Monetary Fund-World Bank (IMF-WB). IMF supervision and enforcement of these reforms via conditionality and Structural Adjustment Programs (SAPs) has become an increasingly common way of conveying credibility to private investors. In this sense, emerging economies 'import' or 'borrow credibility' from the IMF via conditionality and SAPs (Cottarelli and Giannini 1997). As a monitor and an enforcer of reform programs, the IMF acts as a kind of 'agency of restraint' that minimizes "investors' risk of policy reversal and therefore helps to establish the credibility of the chosen policy options vis-à-vis market participants" (Dhonte 1997, 6-7). Thus, IMF conditionality and SAPs assure investors that governments will not bend to popular pressures to abandon the 'right' policies. The penalties for policy reversal include withdrawal of IMF financial and technical support and private capital flows. For example, in the case of Latin American economies since the late 1980s, IMF conditionality and SAPs have clearly enhanced the credibility of neoliberal reforms in the eyes of domestic and foreign private investors (Dhonte 1997).

\subsection{Credibility Theory and Institutional Reform}

5 Grabel (1999) treats the crisis of 1997-8. 
The theory of policy credibility has been extremely influential in informing the design and operation of the institutions that govern monetary and exchange rate policy in emerging economies (namely, central banks and currency boards). The logic of extending credibility theory to financial policymaking is rather straightforward: to be credible, financial policy must be insulated from the vagaries of the political process, where shortsighted political goals often predominate. In the absence of this insulation, financial policy can be manipulated instrumentally by governments seeking to garner political support. Aware of this possibility, the (rational) public will know that announced financial policies "may lack credibility because they are economically inconsistent or politically unsustainable" (Schmieding 1992, 45-6).

Problems of financial policy credibility may also arise if policymakers have a history of strategically reneging on policies they previously committed to in order to achieve a short-term political or economic objective. This is the problem of 'time inconsistency' (Kydland and Prescott 1977). ${ }^{6}$ In this context, rational economic actors are likely to expect policy reversals and will act accordingly (such as by hedging against reversal). At best, the policy will therefore fail to induce the intended results; at worst, it will be sabotaged. Financial policy credibility (and hence, success) may also be threatened if financial and fiscal policies are at cross purposes, introducing the problem of 'Stackelberg warfare' (Blackburn and Christensen 1989).

In the new-classical view, gaining the public's confidence in the technical abilities and the anti-inflationary resolve of financial authorities in emerging economies is no simple matter. In such countries it is reasonable to expect that the public will have limited confidence in both the personnel of financial policy-making institutions and in the likelihood that the institution will be able to stay the course of politically unpopular policies. It is even reasonable for the public to question the longevity of new or reformed financial policy-making institutions. These uncertainties may stem from the immaturity of the institutions themselves, from the legacy of high inflation, and/or from the rapid turnover of personnel in the government and financial institutions (Schmieding 1992, 45-6). In this context, new-classical theory maintains that it is necessary to staff politically insulated financial policy-making institutions with nonpartisan technocrats in order to establish policy credibility.

A 'credible financial policy-making institution' may thus be defined as one that is able to operate without "instruction, guidance, or interference from the government" (Henning 1994, 63). The hallmark of these credible institutions is their willingness to implement and sustain correct policy, even in the face of short-term dislocations that they might induce. Freed from undue

6 Persson (1988) surveys the time inconsistency literature. 
political influence, these autonomous institutions achieve credibility by demonstrating a steadfast commitment to the neoliberal agenda. Thus reassured, economic actors will rationally commit to behaviors that promote the success of neoliberalism and, thereby, the welfare of society.

\section{3.i Central Banks}

Independent central banks have recently been established in many Latin American countries, including Argentina, Chile, Colombia, Mexico, and Venezuela. In the former socialist countries independent central banks have recently emerged in Albania, Armenia, Bulgaria, the Czech Republic, Estonia, Hungary, Poland, and Romania (Loungani and Sheets 1995). ${ }^{7}$ In the context of the Asian financial crisis of 1997-8, governments in the region have committed to create independent central banks as a precondition for IMF assistance. The rise of independent central banks reflects the widespread acceptance of the theoretical view that monetary policy credibility is strengthened by central bank autonomy. The IMF also exerts pressure on emerging economy governments to establish independent central banks in myriad ways, such as through extensive advising and training of bank officials and SAPs.

The case for independent central banks in new-classical theory follows rather directly from the general views on the prerequisites for credible policy (described above). Central bank independence imparts a degree of credibility to monetary policy which cannot be achieved when policy is developed by elected politicians. This credibility stems from the political insulation of the institution. Armed with respect for the precepts of new-classical theory and protected by institutional barriers from political contamination, the nonpartisan technocrats who staff independent central banks are able to pursue credible (and time consistent) monetary policy in pursuit of an anti-inflationary course for the national economy (Blackburn and Christensen 1989). ${ }^{8}$

Given the ability of independent central banks to carry out painful deflationary programs in emerging economies, there is a rather direct link between neoliberal reform and efforts to reorganize central bank governance. As Bowles and White $(1994,237)$ write:

\footnotetext{
7 Whether legal independence translates into operational independence is an important consideration. For example, among the former socialist countries, the Armenian, Hungarian, Polish, and Romanian central banks are seen to have less operational independence than the Albanian, Bulgarian, Czech Republic, and Estonian central banks (Loungani and Sheets 1995). In view of the problems with inferring operational from legal independence, Cukierman et al. (1992) develop several measures of central bank independence in a study of seventy-two countries (cf. Maxfield 1994).

8 It should be noted that some new-classical development economists have argued that fiscal policy should also be designed by an independent authority in order to preclude the possibility of Stackelberg warfare (e.g., Mas 1995).
} 
[A]lthough the case for central bank independence is primarily based on providing lower inflationary outcomes, it also resonates with a wider agenda aimed at restoring 'discipline' and 'credibility' to economic decision-making in general.

Maintaining central bank independence is one way that the public and (domestic and foreign) investors can be assured that the central bank will be able to pursue anti-inflationary monetary policy and hence foster a favorable investment climate.

A vast empirical literature seeks to substantiate the theoretical claims for the antiinflationary performance of independent central banks. Initial studies focused on central banks in developed countries; these tended to confirm the hypothesis (Alesina and Summers 1993; Blackburn and Christensen 1989). More recently, efforts have been undertaken to substantiate these claims in the context of emerging economies. An empirical study of twelve former communist countries finds that countries with independent central banks experience lower levels of inflation and greater macroeconomic stability than do countries with dependent central banks (Loungani and Sheets 1995). However, a substantial body of empirical work on emerging economies finds the opposite- that central bank independence neither accounts for observed price stability nor leads to positive economic outcomes (Bowles and White 1994; Cardim de Carvahlo 1995-6; Cukierman et al. 1992; Mas 1995; Maxfield 1994).

Despite the ambiguous empirical basis for advocating central bank independence in emerging economies, independence is now taken as a necessary (though not sufficient) step for achieving monetary policy credibility. Where central banks are new institutions (as in the former communist countries) or where the public has little confidence in these institutions, it may also be necessary to import central bank credibility by adopting the actual operating guidelines of credible Western central banks or by importing central bank staff directly (Schmieding 1992, 55). Indeed, the German Bundesbank Law has been adopted by the new Polish, Hungarian, Czechoslovak, and Bulgarian central banks (Schmieding 1992, 55-8, fn 59). Credibility can also be created via externally imposed constraints on central bank operations. Such constraints are often embodied in IMF SAPs which tie financial and/or technical assistance to the central bank's adherence to certain operating practices, such as the refusal to finance government debt (Schmieding 1992, $62)$.

The adoption of rule-based-rather than discretionary-monetary policy may also enhance central bank credibility. These rules often take the form of monetary growth rules or inflation targets. As before, this may involve importing credible rules from abroad. But central 
bank credibility will only be enhanced by these constraints as long as the rules themselves do not introduce time inconsistency or Stackelberg warfare, and as long as the public is confident that the rules will not be breached. This introduces a game-theoretic dilemma in which central banks must search for increasingly credible means by which rules can be enforced. If the public does not find the central bank's commitment to policy rules sufficiently credible, then the central bank may seek to have these rules incorporated into the legal system of the country. If mere laws are not sufficiently credible, then a constitutional amendment might be pursued (a 'meta-rule') (Schmieding 1992, 50). Perhaps because of the problem that investors tend not to trust governments to stick to their own rules, central bank reform efforts tend to side-step rule-based policy. ${ }^{9}$ Instead these efforts more modestly aim to establish institutional independence.

\section{3.ii Currency Boards}

A currency board is a monetary institution that issues local currency fully backed by stocks of a hard foreign 'reserve currency.' By law, the local currency is fully convertible upon demand and without limit into the foreign reserve currency at a fixed rate of exchange. The rate of exchange between the local and the foreign reserve currency is inviolable: the IMF recommends that the exchange rate be written into the currency board's constitution (IMF 1996; Hanke et al. 1993). The reserves held by the currency board consist of low-risk, interest-earning securities and other assets payable in the reserve currency. The amount of foreign reserves held by the currency board must typically be equal to 100 to 110 percent (as set by law) of the value of the local money stock.

Historically, some seventy countries have operated currency boards. Today, currency boards are operating in Bulgaria, Bosnia, Lithuania, Argentina, Estonia, Hong Kong, Bermuda, Cayman Islands, Falkland Islands, Faroe Islands, Gibraltar, and Djibouti. ${ }^{10}$ Recent reports by the IMF and consultants to the institution use the success of existing boards in Argentina, Estonia, and Hong Kong as a basis on which to argue for their adoption elsewhere (Enoch and Gulde 1997; Ghosh et al. 1998; Hanke 1997; IMF 1997, 1996; Santiprabhob 1997). ${ }^{11}$ At the cost of severe recessions, the Estonian board is credited with having stabilized the economy, the Argentine board with having ended inflation and maintaining stability during the Mexican financial

9 However, currency board operations are rule based (see below).

10 Ghosh et al. (1998) and Hanke et al. (1993, App. C) describe all current and past currency boards.

11 For example, in the period prior to the Brazilian election in October 1998 and the IMF's 'preventative bailout' of the country, Dornbusch proposed the adoption of a currency board modeled on Argentina's successful use of the institution. 
crisis of $1994-5$, and the Hong Kong board with having maintained stability during the Asian financial crisis and during the transition from British to Chinese rule.

From the perspective of new-classical theory, currency boards have much to recommend them. Currency boards provide a highly credible way of managing exchange rates in emerging economies (Caramazza and Aziz 1998). The credibility of the local currency may be enhanced via the direct link to hard foreign currency holdings. The public can thus be confident in the ability of the currency board to prevent debasement of the local currency. ${ }^{12}$ As long as the currency board has sufficient holdings of the foreign reserve currency, investors and the general public can be confident of the board's ability (not just its willingness) to maintain a fixed exchange rate (Bhattacharya 1997; Enoch and Gulde 1997; Santiprabhob 1997). Even though new-classical economists generally reject fixed exchange rate regimes, the fact that currency boards have a legal and institutional commitment to maintain fixed rates renders them highly credible (Ghosh et al. 1998). ${ }^{13}$ This confidence in the fixed exchange rate may prevent the public from engaging in currency substitution, destabilizing speculation against the currency and, more generally, actions that will undermine the stability of the domestic monetary system. Hence, even though currency boards do not render speculation against the currency impossible, they reduce the chances that speculators will lose confidence in the currency.

Currency boards complement the operations of independent central banks by providing another means by which the private sector can be assured that monetary management will proceed undisturbed by political pressure. Indeed, currency board credibility is seen to exceed that of independent central banks. This is because currency boards have responsibility for a very narrow set of tasks, while central banks (independent or not) have a broad range of responsibilities. Currency boards help fill the 'credibility deficit' that confronts even independent central banks in countries where these institutions are new or where they have a poor track record. Like central banks, they are to be autonomous-with their members drawn from the ranks of technocrats, economists, and bankers and appointed for multiple-year terms-to ensure that exchange rate policy is in the hands of an independent authority that does not have strategic incentives to veer toward an expansionary course.

Currency boards epitomize the credibility advantages of rule-based financial policy; in all cases where currency boards have existed, they have operated in accordance with a strict set of

12 Indeed, a recent empirical study finds that inflation in countries with currency boards is $4 \%$ lower than in countries with other types of pegged exchange rate regimes (Ghosh et al. 1998) 
simple, transparent rules. Hence, they possess even less scope for discretion than do independent central banks. These legally (and in some cases constitutionally) binding rules, coupled with institutional independence, preclude currency boards from ceding to political pressures for monetary expansion. The association between currency board credibility and ('meta-')rule-based operations echoes previously discussed aspects of new-classical theory. As one prominent proponent of currency boards put it: "[al]though the rational expectations school has never considered in detail a currency board, the arguments...lend support to the case for currency boards, since currency boards are rule-bound and have no discretion in monetary policy" (Hanke et al. 1993, 39).

As with independent central banks, the credibility of currency board rules may be enhanced by introducing credible external mechanisms for ensuring compliance with the rules. This may involve efforts to import credibility by placing representatives of foreign central banks or multilateral institutions on currency boards or by conditioning external financial or technical support on the compliance of the currency board with predetermined rules.

A model currency board constitution prepared for Russia by US consultants contains just such provisions for importing credibility from abroad. The proposed constitution requires a majority of the members of the board of directors to be foreigners, to "help prevent the government from bending the rules of the currency board" (Hanke et al. 1993, 110). Some analysts have proposed that even external enforcement of currency board credibility will be an inadequate guarantor of its independence. For example, Dornbusch (1997) proposes that the Mexican government cannot be trusted to leave a currency board unmolested. For this reason he proposes that Mexico take the extreme measure of importing currency credibility by simply adopting the US dollar as its currency.

It should be emphasized that the contemporary appeal of currency boards may derive from the complementarity between board operations and neoliberal economic reform. In a general sense, currency boards-like independent central banks and IMF SAPs_enhance the credibility of neoliberal reforms because they assuage investor fears of policy reversal by constraining the discretionary

13 The IMF rejected an Indonesian plan to implement a currency board in February 1998 because the government's commitment to a fixed exchange rate lacked credibility due to low reserve holdings and political instability. 
authority of elected governments. More specifically, the complementarity between currency boards and neoliberal reform is apparent when one considers the central role of efforts to promote reductions in government spending, privatization, and increased external openness in neoliberal programs. Given that currency board rules preclude the printing of fiat money by central banks, currency boards provide a mechanism for ensuring that governments exercise fiscal discipline. Privatization is reinforced by the same ban on the printing of fiat money since central banks cannot be used to provide aid to ailing state-owned enterprises (Hanke 1997).

Currency board operations also complement neoliberal reforms that promote external economic openness. Currency board rules stipulate that the local money supply can be increased only following an increase in foreign exchange holdings. An increase in foreign exchange holdings may result from improved net export performance or from private capital inflows. Hence, expansion of the local money supply is predicated on the success of capital and current account liberalization.

\section{Rejecting the Credibility Criterion}

We now turn to a critical assessment of the use of the credibility criterion as a means of privileging the neoliberal reform agenda and its policy and institutional corequisites.

\subsection{Credibility and Neoliberal Reconstruction}

Recall that a key premise of the credibility criterion is that all agents in an economy uniformly derive their expectations about the consequences of an economic reform program from the same 'correct' new-classical model (i.e., the rational expectations hypothesis). If instead agents rely on different models when forming expectations, then they will pursue behaviors that generate unpredictable macroeconomic outcomes, including outcomes that jeopardize the viability of the reform program (Frydman and Phelps 1983; McCallum 1983). Thus, a rejection of the assumption of rational expectations complicates ex-ante judgements regarding the credibility of any economic program (including, but not limited to neoliberal reform).

For the sake of argument, however, let us assume that agents form their expectations rationally and that under normal circumstances economic agents do assign the identical, correct 
probability distribution to the likelihood of a policy's effects and to the likelihood of its failure or reversal. The rational expectations presumption is nevertheless implausible in the case of a unique policy reform such as a full-scale neoliberal reform. As Lucas (1973) and Backus and Driffill (1985) note, the nonrecurrent nature of regime shifts affords no basis for applying past learning. Hence, agents might be expected to form diverse and inconsistent subjective probability distributions regarding a policy's affects and longevity and take actions that undermine the new policy regime (Conley and Maloney 1995). Complicating matters further, the adjustment of expectations and behavior in the wake of regime shifts occur in real time. In the process of adjustment we must recognize the influence of any number of informational asymmetries and imperfections that will necessarily affect agents' decisionmaking (Agenor and Taylor 1992). The behavior of agents in the short run, then, may very well generate economic outcomes that are inconsistent with long-term policy objectives.

All of these complications are seemingly ignored by today's neoliberal policymakers and their economic consultants. Their implication, after all, is that policy design is a much trickier business than new-classical economists have thought.

\section{1.i Credibility and Democracy}

I say 'seemingly' ignored because they are in fact dealt with implicitly and, unfortunately, with severe undemocratic implications. This is indeed the most problematic aspect of the way in which the criterion of policy credibility has been incorporated in theoretical and policy debate. This criterion has been exploited to discredit and prevent the implementation of all non-neoliberal economic programs, including gradualist reforms in some former communist countries.

On its face, the proposition that credible policies are more likely to succeed seems entirely innocuous. But in the volatile political context in which neoliberal programs were and are introduced in emerging economies, this criterion has a malevolent import. We can expose this malevolent aspect by reducing the new classical approach to policy and institutional credibility to a straightforward set of propositions. The propositions may be stated as follows: 1) An economic regime (policy or institution) will garner credibility only to the degree that it is likely to survive; 2 ) an economic regime is likely to survive only to the degree that it attains its stated objectives; 3 ) an economic regime is likely to achieve its stated objectives only to the degree that it induces behaviors (in the aggregate) that are consistent with these objectives; 4) an economic regime is likely to induce consistent behaviors only to the degree that it reflects and operationalizes the true theory of market economies; and 5) an economic regime reflects the true theory of market economies only to the degree that it is new-classical. 
The exclusionary, dissent-suppressing maneuver that has been undertaken here is captured in propositions four and five. Alternative economic theories are summarily banned on the grounds that they could not possibly meet the unforgiving credibility test, because they could not possibly be true. Hence, policy regimes founded upon them must collapse, in part because of the inconsistent behaviors they necessarily induce. Writing on the intellectual maturation of the new-classical economics, Frydman and Phelps (1983, 27-8) identify this aspect of new-classical economics as a barrier to intellectual pluralism. In their words, the "thoroughgoing implementation of the rational expectations method in policy-making would entail the official promotion, or 'establishment,' of one model over others" (27-8).

Notice the epistemological foundation of this perspective: governments and their foreign economic advisors impute credibility to policies based on the purported truth of the abstract theory from which these policies derive. Economic scientists in possession of the singular true model appear as omniscient, benevolent figures issuing policy edicts for the betterment of citizens in the target countries. In the cases where neoliberal reform programs are designed by national governments themselves (for example, the present Cardoso administration in Brazil), foreign economic advisors nevertheless play an important role in strengthening the hands of governments against their domestic critics (Fischer 1997, 26). The best that could be said of dissent against neoliberal reforms — whether in the streets or in the academy—is that it threatens to disrupt the credibility of the instituted polices by undermining confidence in them and inducing inconsistent expectations, thereby jeopardizing the entire neoliberal policy regime. In both these respects-the theoretical and the political-the credibility criterion discredits the plurality of views and denies the value of dissent, both hallmarks of liberal democratic society.

\section{1.ii The Endogeneity of Credibility}

In assuming the exogeneity of policy credibility, new-classical theorists deny the significance of factors endogenous to all societies which significantly influence the likelihood of a policy's success and hence its credibility. ${ }^{14}$ Notably absent from new-classical accounts, for instance, are considerations of class conflict and the distribution of income, wealth, and political power. In the particular case of the neoliberal experiments in emerging economies, the credibility of these programs is secured not by their exogenous properties-their truth status-but by enforcement strategies of domestic and foreign capital and the state. Together, these actors have often repressed trade unions, abused human rights, stifled dissent, and relied on the

14 See the discussion of these issues in Burkett and Lotspeich (1993) and Burkett (1997). 
support and financial resources of international and domestic elites, foreign governments, and multilateral institutions in order to sustain the neoliberal agenda. The credibility of neoliberal policies is secured, then, through the mobilization of political and economic power. It does not arise as the natural result of autonomous decision-making of economic actors forming rational judgements about the future and pursuing voluntary courses of action that validate these policy options.

From this perspective, the support of foreign capital in the form of inflows of direct foreign and portfolio investments or loans (or the threat of withdrawal) is critical because it creates policy credibility rather than simply reveals it. The importation of outside 'experts' plays the same role: the act of 'signaling credibility' should be understood to produce the effect of credibility rather than merely to reveal something that was already there, latent in the regime itself. In addition to the policy credibility created by foreign experts, domestic experts likewise play a role in validating neoliberal reforms. US economics faculties have long sought to export neoliberal thinking to emerging economies via economics education in the US and via educational programs sited in emerging economies. The University of Chicago's work with Chilean economists in the 1970s is the most well-known such effort (Becker 1997). Recently, a consortium of US universities have embarked on a similar program to retrain Russian university economics lecturers (Wu 1997).

Recent events in emerging economies exemplify these arguments about endogenous policy credibility. During the 1995 Argentine election the IMF, domestic and international capital, and the state jointly acted to demonstrate the credibility of the government's commitment to neoliberal policy. In this case, policy credibility was secured via private and multilateral financial support (and the threatened withdrawal thereof) and through state repression of dissent against neoliberalism (Richards 1996). ${ }^{15}$ Prior to 1998 the Russian government was able to use effectively external financial support and political repression in order to signal private investors that its commitment to neoliberal reform was credible. In the conflict between the imposition of neoliberalism and the popular will, the Russian government opted for the former over the latter (Gowan 1996). ${ }^{16}$ The 'preventative bailout' of Brazil by the IMF in the fall of 1998 similarly was seen by domestic and foreign investors to strengthen the commitment of (newly re-elected)

15 In this election, President Menem was able to suppress popular dissent against neoliberal policies by promising that dire circumstances (such as investor flight) would necessarily follow any attempt to veer from the neoliberal course that he charted during his first term. Had he been defeated, his predictions might well have been confirmed in part because of the expectations of flight that his own campaign induced! 
President Cardoso to press forward with his neoliberal reform agenda. Finally, the Estonian currency board experiment has largely been kept afloat by Finland and Sweden for geopolitical reasons. Investors in Argentina have been calmed by the promise of a preventative bailout (as in Brazil) should Argentina start to fall.

More generally, IMF-WB financial and technical support and SAPs play a pivotal role in maintaining investor confidence in the credibility of neoliberal reforms (Cottarelli and Giannini 1997). For example, IMF-WB supervision of the Mexican economy's neoliberal reform following its $1994-5$ crisis was critical to the renewed confidence of foreign investors in the economy. Following the Asian financial crisis of 1997-8, private investors are watching closely the manner in which the IMF is able to strengthen the hands of domestic reformers in the region and enforce adherence to radical neoliberal reform aimed at dismantling the 'Asian model' of development.

Conversely, it must be acknowledged that non-neoliberal economic programs are made endogenously in-credible because those regimes that attempt to put them into place are often unable to prevent domestic and international capital from engaging in activities that undermine the programs. These regimes typically face capital flight and/or the withdrawal of external loans, aid, trade credits, and technical assistance programs. For example, in its 1996 negotiations with Bulgaria and Bosnia the IMF explicitly tied the continued receipt of financial support to creation of currency boards (Ghosh et al. 1998; Bhattacharya 1997). In the early 1990s the Polish, Hungarian, and Czechoslovac governments were forced by the IMF to abandon plans to pursue non-neoliberal economic programs involving industrial development strategies and state financing mechanisms. IMF-WB financial and technical assistance programs to former communist countries stipulate that recipients can neither place restrictions on foreign direct investment nor encourage development banking. The Polish case is particularly dramatic in this regard: the terms of a WB loan agreement constrained the ability of the Polish Development Bank to issue direct, subsidized industrial loans. Moreover, these multilateral institutions have even barred former communist countries from pursuing gradualist reform or state capitalist models (Gowan 1995, 1996; Amsden et al. 1994). These same options were ruled out of court as well in the Baltic republics of Estonia, Latvia, and Lithuania.

I am arguing here that the way in which the credibility criterion is presently understood by new-classical theorists and policy advisors reflects a particularly naive vision of society. That vision is of a society marked by homogeneous and harmonious goals and expectations and in

${ }^{16}$ As of this writing (spring 1999), the chaotic state of Russian politics (and the IMF's threatened withdrawal of support) demonstrates just how difficult it can be for advocates of neoliberal reform to secure credibility. 
which governments, to the extent that they can free themselves from interest groups, are able to implement policies designed to secure these goals. In short, it is a vision of society free of class and other social and economic conflicts. What is absent from this view is an understanding that in societies that are stratified by wealth, class, and power, all economic policies are inherently biased in terms of their effects. Policies always serve some interests against others. Hence, policy credibility, in the context considered here, always means securing the willing consent of some groups and the coerced acquiescence of others. This conflict-based view of policy is of course no less true of neoliberal regimes than of other regimes. Credibility, in short, is founded on politics, not metaphysics. ${ }^{17}$

\subsection{Credibility and Institutional Reform}

Many critics have argued that autonomous monetary authorities are incompatible with the principles of democratic governance. After all, critics argue, monetary and exchange rate policies can and do have substantial distributive effects. Hence, these institutions must be accountable to elected government officials and, thereby, to the electorate.

New-classical economists dispense with this criticism in part by claiming that monetary institutions must be insulated from political pressures so as to ensure monetary policy credibility, as we have seen. But this defense makes sense only if we are prepared to accept the epistemological claims of newclassical theory and the unified, harmonious view of society described above. Only in this case is it legitimate to view the autonomous monetary authorities as the champion of the national interest. If there is only one true economic theory, then the insulation of monetary institutions from political influence hardly amounts to a democratic deficit. The same is true if all citizens share the same values, interests, and goals and if they will all be affected by a particular policy in the same way. And as I have just argued, this is precisely the view taken by the new-classicals. In this view, only a nonaccountable monetary authority can

\footnotetext{
17 Hence, non-neoliberal economic programs are not necessarily credible or in-credible. In the context of global neoliberalism, national governments find their ability to pursue non-neoliberal courses to be seriously constrained (see DeMartino 1999).
} 
guarantee the kind of economic outcomes that all of society's members ultimately want.

But if we adopt instead the alternative social model offered here, one in which conflict in economic interests, values, and goals is endemic to all societies, then the autonomy of monetary authorities may be read as an objectionable abridgement of democratic accountability. From this perspective, independent central banks and currency boards are hardly apolitical; they "do not exist 'above' or 'outside' politics" (Bowles and White 1994, 240), but instead represent a strategic means by which some groups seek to secure their own economic interests at the expense of the interests and goals of others. Policy-making institutions that are structurally precluded from capture by elected officials do not operate in some presumed 'general' or 'national' interest but in accordance with the particularist interests of some and against the particularist interests of others. In the case of independent central banks and currency boards that pursue neoliberal policy, economic elites represent the interest group whose concerns about monetary and exchange rate policy are paramount.

One of the challenges of democratic society is to find ways to mediate the opposing claims of contending social groups. New-classical theorists attempt to do what is simply impossible: to sidestep this challenge by pretending that it does not exist. In so doing they have unwittingly produced a set of institutional reforms that allow those already best off in society to further their own economic interests-all under the cover of apparently scientific economic theory. They therefore have a hard time accounting for the tremendous opposition to neoliberal reform regimes that have been instituted across the emerging economies. What may be worse, when such opposition emerges, the theoretical premises described above leave them with little basis for opposing authoritarian measures. In the choice between democratic turbulence and authoritarian stability, the credibility criterion endorses the latter. 
Finally, the credibility criterion has both dissent-suppressing and tautological attributes. As this criterion is presently employed, it precludes any substantive empirical refutation of the neoliberal program. It can always be claimed ex-post that the environment in which neoliberal programs were implemented was not credible and thus that the failure of the policies to achieve their intended results does not stem from flawed prescriptions. This is indeed the most commonly employed explanation offered for the failure of the neoliberal experiments in the Southern Cone and for the difficulties encountered by the former socialist countries. ${ }^{18}$ As a consequence, this criterion precludes any meaningful empirical verification or refutation of the policies inspired by new-classical theory.

\section{Alternative Credibility Criteria}

In view of the antidemocratic, antipluralist implications of the contemporary use of the credibility criterion, I suggest in what follows the basis for two alternative means by which policy and institutional reforms could be judged.

\subsection{Democratic Credibility: Proliferating Veto Points}

As argued above, the credibility of all economic policy regimes is inherently endogenous. In this case, we must take account of the distribution of power in society as we ascertain the

credibility of any particular regime. One useful way to think about this is in terms of what Tsebelis (1995) calls 'veto points.' Under different social structures, different critical actors are better or less able to veto or otherwise influence policy success through their behavior. Occupants of important veto points enjoy a disproportionate ability to defeat a policy regime that they oppose. We can safely say that under a neoliberal policy regime, business interests and especially wealthy investors occupy the most powerful veto points. Hence, to weight policy credibility as a fundamental objective under such conditions merely rewards the wealthy for their existing privilege. In contrast, progressives ought to seek a social structure that transfers meaningful veto authority to the least advantaged sectors of the population; then, and only then, should credibility be treated normatively as a valid decision variable.

18 The other explanation offered is that these programs were improperly sequenced (Grabel 1996a). Gowan (1995) discusses Sachs's efforts to account for the disappointing early results of these reforms. 
We may attempt to operationalize this admittedly abstract idea of democratizing veto authority by developing a progressive criterion for economic policy credibility, termed here the 'principle of democratic credibility.' This criterion does not reject the idea of policy credibility but rather substantially broadens the range of potential policy veto authority while weakening the truth standard against which policy credibility should be adjudicated. Using the principle of democratic credibility, only those economic policies that are not apt to be vetoed by the least advantaged, were they to have the power to do so, would be deemed credible. Using this standard, macroeconomic policies are not deemed true and hence credible only to the extent that they operationalize one theory of the economy-that attributed to new-classical theory. Rather, this agnostic standard allows for the credibility of a range of alternative economic programs, provided that these programs are validated by the broader citizenry. Using this criterion, heterodox or expansionary economic programs would not be ruled exogenously in-credible; instead, their sabotage by the self-fulfilling actions of elites and the economic policy community would be seen as an illegitimate exercise of political power in defense of the particularist interests of those already best off. Exposing the endogeneity of policy credibility might serve to enable more effective resistance to these behaviors and would provide support for measures (such as capital controls) that curb the ability of particular social groups to undermine democratically instituted policies that they oppose. Then and only then would we be able to discern the credibility of a heterodox or an expansionary economic program.

By itself, this standard does not in any way guarantee that only progressive economic policies will be implemented, of course. Other complementary criteria for adjudicating economic policy must be pursued alongside this one. For example, such additional criteria might focus on whether economic policies are guided by egalitarian goals.

Adjudicating the democratic validation of macropolicy regimes is of course a complicated matter, one that is necessarily tied to culturally determined understandings of enfranchisement and democracy. Such assessments are additionally complicated by the class-based nature of society. At a minimum, this adjudication should reflect the views of groups such as the poor and other often disenfranchised populations. As radical as this standard might appear, it is neither stronger nor more restrictive than the credibility criterion employed today. Indeed, unlike the authoritarian new-classical criterion, which determines in advance of all debate the appropriate policy regime, this flexible standard allows for dynamic pragmatic adjustments, reflecting a collective learning-by-doing, as a normal outcome of democratic governance (see Tool 1979, ch. 15). Moreover and finally, against the new-classical vision, a democratic approach would 
embrace and emphasize a range of higher criteria to be used in the specification of macropolicy, such as respect for human and labor rights.

The trend toward the creation of independent central banks and currency boards flies in the face of the principle of democratic credibility. Indeed, the very credibility of independent central banks and currency boards stems directly from their insulation from the population and the degree to which technocrats are able to exert unilateral control over decision-making. By contrast, democratic central bank and currency board representation requires those major social and economic groups that are demonstrably affected by monetary and exchange rate policy, and who may have divergent interests vis-à-vis policy, to have some means to influence policy direction. ${ }^{19}$ This view necessarily rejects the notion that all constituencies in society ultimately benefit from one particular 'good' financial policy. Rather, given the wide-reaching distributive effects of financial policies it is critical that the goals and implementation of policy be debated and democratically determined in order to take account of the divergent agendas or needs of different constituencies.

\subsection{The Principle of Fallibility}

A second criterion for assessing macropolicy formulation and the governance structure of monetary policy-making institutions follows directly from the foregoing critique of the credibility thesis. I call this the 'principle of fallibility.'

The principle of fallibility begins with the presumption that the premises on which economic policies are founded are necessarily inherently imperfect. I have alluded to some of the difficulties in this regard in the previous discussion of the complexity of such a seemingly straightforward concept like credibility, which is undermined by differences among agents' expectations, etc. Thus it follows that the outcome of macroeconomic policy can not be predicted with certainty in advance of implementation. The principle of fallibility therefore simply calls for humility on the part of policymakers and economists.

The recognition of fallibility has clear implications for the content of economic policy and the conduct of financial policy, especially if one takes seriously traditional liberal and left concerns about economic inequality. The fallibility criterion requires that economic policymakers and monetary authorities adopt a conservative standard for policy design which might not only target the improvement of the economic circumstances of the most disadvantaged groups but also minimize the harm to the least advantaged, in the event that a chosen policy fails. This standard 
is similar to the institutionalist criterion of minimal dislocation from economic policy, termed the 'fundamental principle of economics' (Foster 1981).

This criterion differs from the 'meso policies' proposed by Stewart (1992) and others. Meso policies are policies that are implemented alongside macropolicies with the express purpose of mitigating the adverse economic effects of these policies on economically vulnerable groups. While the proposals for meso policies are guided by laudable humanitarian concerns, they give too much ground: they cede to new-classical theory the validity and, hence, inevitability of the macroeconomic policy regimes that meso policies are designed to ameliorate.

\section{Conclusion}

I have argued that the application of credibility theory to policy and institutional reforms in emerging economies has substantial antidemocratic effects. Given that only neoliberal policies can survive the demanding credibility test, the suppression of dissent becomes an instrumental means toward the advancement of the common good. In contrast, adoption of the standard of 'democratic credibility' would reinstate public debate and dissent as integral components of democratic policy-making, especially in stratified societies. Moreover, recognition of the 'principle of fallibility' might induce humility among policymakers and encourage them to consider the possible adverse consequences of macropolicy regime shifts and institutional reform prior to their implementation. Together, the adoption of these two principles would entail public debate over the distributive consequences of different types of macropolicies and institutional structures, something that is generally lacking as a criterion for policy evaluation today.

19 See Epstein (1988) on democratic central bank governance and Arestis and Bain (1995) on setting Keynesian goals for central banks. 


\section{References}

Agnenor, P.R. and M. Taylor. 1992. "Testing for Credibility Effects." IMF Staff Papers 39 (3).

Alesina, A. and L. Summers. 1993. "Central Bank Independence and Macroeconomic Performance: Some Comparative Evidence." Journal of Money, Credit and Banking 25 (2).

Alesina, A. and G. Tabellini. 1988. "Credibility and Politics." European Economic Review 32.

Amsden, A., J. Kochanowicz, and L. Taylor. 1994. The Market Meets Its Match. Cambridge, MA: Harvard University Press.

Anderson, T. and P. Hill, eds. 1996. The Privatization Process. Maryland: Rowman \& Littlefield.

Arestis, P. and K. Bain. 1995. "The Independence of Central Banks: A Non-Conventional Perspective." Journal of Economic Issues XXIX (1).

Backus, D. and J. Driffill. 1985. "Rational Expectations and Policy Credibility Following a Change in Regime." Review of Economic Studies LII.

Becker, G. 1997. "Latin America Owes a Lot to Its 'Chicago Boys'." Business Week 22 (9 June).

Bhattacharya, R. 1997. "Pace, Sequencing and Credibility of Structural Reforms." World Development 25 (7).

Blackburn, K. and M. Christensen. 1989. "Monetary Policy and Policy Credibility: Theories and Evidence." Journal of Economic Literature XXVII.

Bowles, P. and G. White. 1994. "Central Bank Independence: A Political Economy Approach." Journal of Development Studies 31 (2).

Burkett, P. 1997. "Democracy and Economic Transitions." Studies in Political Economy 52.

Burkett, P. and R. Lotspeich. 1993. "Review essay: The Order of Economic Liberalization: Financial Control in the Transition to a Market Economy (R. McKinnon)." Comparative Economic Studies 35 (1).

Caramazza, F. and J. Aziz. 1998. "Flexible or flexible: Getting the Exchange Rate Right in the 1990s." IMF Economic Issues 13.

Cardim de Carvalho, F. 1995-6. "The Independence of Central Banks: A Critical Assessment of the Arguments." Journal of Post-Keynesian Economics 18 (2).

Conley, J. and W. Maloney. 1995. "Optimal Sequencing of Credible Reforms with Uncertain Outcomes." Journal of Development Economics 48. 
Cottarelli, C. and C. Giannini. 1997. "Credibility without Rules?" IMF Occasional Paper 154, December.

Cukierman, A., S. Webb, and B. Neyapti. 1992. "Measuring Independence of Central Banks and its Effect on Policy Outcomes." World Bank Economic Review 6 (3).

DeMartino, G. 1999. "Global Neoliberalism, Policy Autonomy, and International Competitive Dynamics." Paper presented at the annual meetings of the Association for Evolutionary Economics, 3-5 January.

Dewatripont, M. and G. Roland. 1995. "The Design of Reform Packages under Uncertainty." American Economic Review 85 (5).

Dhonte, P. 1997. "Conditionality as an Instrument of Borrower Credibility." IMF Working Paper on Policy Analysis and Assessment 2, February.

Dornbusch, R. 1997. "Mexico Should Ditch the Peso for the Dollar." Business Week 22 (19 May).

Economist, 1997. "The Great Escape.” 69 (3 May).

Enoch, C. and A.-M. Gulde. 1997. "Making a Currency Board Operational." IMF Working Paper on Policy Analysis and Assessment 10, November.

Epstein, G. 1988. "Democratizing the Fed Is a Necessary First Step." Dollars and Sense 136.

Fischer, S. 1997. "Applied Economics in Action: IMF Programs." American Economics Review 87 (2).

Foster, J. F. 1981. "Current Structure and Future Prospects of Institutional Economics." Journal of Economic Issues 15.

Frydman, R. and E. Phelps eds. 1983. Individual Forecasting and Aggregate Outcomes: Rational Expectations. New York: CUNY Press.

Ghosh, A., A.-M. Gulde, and H. Wolf. 1998. "Currency Boards: The Ultimate Fix?" IMF Working Paper of the Policy Development and Review Department 8, January.

Gowan, P. 1995. "Neo-liberal Theory and Practice for Eastern Europe." New Left Review 213. 1996. "Eastern Europe, Western Power and Neo-liberalism." New Left Review 216.

Grabel, I. 1996a. "Financial Markets, the State and Economic Development: Controversies within Theory and Policy." International Papers in Political Economy 3 (1).

. 1996b. "Marketing the Third World: The Contradictions of Portfolio Investment in the Global Economy." World Development 24 (11). 
. 1999. "Rejecting Exceptionalism: Reinterpreting the Asian Financial Crises." In J. Michie and J. Grieve Smith, eds., Global Instability and World Economic Governance. London: Routledge.

Hanke, S. 1997. "New Currency Boards Come to the Balkans." Transition 8 (1).

Hanke, S., L. Jonung, and K. Schuler. 1993. Russian Currency and Finance. London: Routledge.

Henning, C. R. 1994. Currencies and Politics in the US, Germany, and Japan. Washington, DC: Institute for International Economics.

IMF (International Monetary Fund) Survey. 1996. Currency Boards Circumscribe Discretionary Monetary Policy. (20 May).

. 1997. Currency Board Arrangements More Widely Used. (2 February).

Kydland, F. and E. Prescott 1977. "Rules Rather than Discretion: The Inconsistency of Optimal Plans." Journal of Political Economy 85 (3).

Loungani, P. and N. Sheets. 1995. "Central Bank Independence, Inflation and Growth in Transition Economies." International Finance Discussion Papers, Federal Reserve System 519.

Lucas, R., Jr. 1973. "Some International Evidence on Output-Inflation Tradeoffs." American Economics Review 63.

Mas, I. 1995. "Central Bank Independence: A Critical View from a Developing Country Perspective." World Development 23 (10).

Maxfield, S. 1994. "Financial Incentives and Central Bank Authority in Industrializing Nations." World Politics 46.

McCallum, J. 1983. "Policy 'Credibility' and Economic Behavior." Journal of Post-Keynesian Economics VI (1).

Murphy, K., A. Shleifer, and R. Vishny. 1992. "The Transition to a Market Economy: Pitfalls of Partial Reform." Quarterly Journal of Economics 107 (3).

New York Times. 1997. "Brazil Passes a Bill to Slash Bloated Public Work Force." A12 (21 November).

Persson, T. 1988. "Credibility of Macroeconomic Policy: An Introduction and Broad Survey." European Economic Review 32.

Polanyi, K. 1944. The Great Transformation. Boston: Beacon Press.

Richards, D. 1996. "The Political Economy of Recent Latin American Elections." Department of Economics, Indiana State University. Mimeograph. 
Sachs, J. 1993. Poland's Jump to the Market Economy. Cambridge, MA: MIT Press.

Santiprabhob, V. 1997. "Bank Soundness and Currency Board Arrangements: Issues and Experience." IMF Working Paper On Policy Analysis and Assessment 11, December.

Schmieding, H. 1992. Lending Stability to Europe's Emerging Market Economies. Tübingen, Germany: J.C.B. Mohr.

Stewart, F. 1992. "Alternative Macropolicies, Meso Policies, and Vulnerable Groups." In G.A. Cornia, R. Jolly, and F. Stewart, eds., Adjustment with a Human Face. Oxford: Clarendon.

Tool, M. 1979. The Discretionary Economy. Santa Monica, CA: Goodyear Publishing.

Tsebelis, G. 1995. "Decision-making in Political Systems: Veto Players in Presidentialism, Parliamentarism, Multicameralism and Multipartism." British Journal of Political Science 25.

Wu, L. 1997. "Retraining Economics Lecturers in Russia." Transitions 8 (2, 17 April). 